\title{
APLIKASI KONSEP ARSITEKTUR ORGANIK PADA BANGUNAN PENDIDIKAN
}

\author{
Ayu Setyoningrum \\ Prodi Arsitektur Fakultas Teknik Universitas Muhammadiyah Jakarta \\ Cempaka Putih Tengah 27 Jakarta Pusat 10510 \\ ayuusn@gmail.com \\ Anisa Anisa \\ Prodi Arsitektur Fakultas Teknik Universitas Muhammadiyah Jakarta \\ Cempaka Putih Tengah 27 Jakarta Pusat 10510 \\ anisa@ftumj.ac.id
}

\begin{abstract}
Abstrak
Arsitektur organik merupakan sebuah konsep arsitektur yang awal mulanya dicetuskan oleh Frank Lloyd Wright.Sejak zaman kecil, Frank Lloyd Wright sering mengamati hubungan yang terjadi antara manusia dengan lingkungannya.Hal tersebut yang menjadi dasar pemikirannya tentang arsitektur organik.Arsitektur organik ini pada dasarnya masih diperdebatkan mengenai panduan maupun batasan untuk desainnya.Namun beberapa peneliti sebelumnya telah mencoba mengamati dan merangkum konsep dari Arsitektur Organik. Arsitektur organik lebih mengacu pada keselarasan dengan alam sekitarnya, menciptakan satu kesatuan yang harmonis, dapat bertahan sepanjang waktu dengan bentuknya yang dinamis dengan alam, serta fungsional terhadap fungsi bangunannya.Fungsi bangunan pendidikan yakni sebagai fasilitas dalam pembelajaran untuk menambah ilmu pada penggunanya. Proses pembelajaran tersebut akan terasa lebih nyaman apabila ruang maupun kegiatanya menjadi satu kesatuan terhadap lingkungannya. Penerapan arsitektur organik pada bangunan pendidikan memungkinkan terciptanya suasana yang segar dalam kegiatan pendidikan. Penelitian ini bertujuan untuk mendapatkan gambaran mengenai penerapan arsitektur organik pada bangunan pendidikan. Metode yang digunakan adalah kualitatif deskriptif yang menganalisis bangunan pendidikan berdasarkan konsep arsitektur organik.
\end{abstract}

Kata-kata Kunci: Arsitektur Organik, Bangunan Pendidikan, konsep arsitektur

\section{APPLICATION CONCEPT OF ORGANIC ARCHITECTURE IN EDUCATIONAL BUILDINGS}

\begin{abstract}
Organic architecture is an architectural concept which was originally coined by Frank Lloyd Wright. Since childhood, Frank Lloyd Wright has often observed the relationships that occur between humans and their environment. This is the basis of his thinking about organic architecture. This organic architecture is still debated about the guidelines and limits for the design. But some researchers have previously tried to observe and summarize the concepts of Organic Architecture. Organic architecture refers more to harmony with the surrounding environment, creates a harmonious whole, can survive all the time with its dynamic form with nature, and functional to the function of the building. The function of educational buildings is as a facility in learning to add knowledge to its users. The learning process will feel more comfortable if space and activities become a unity to the environment. The application of organic architecture to educational buildings
\end{abstract}


enables the creation of a fresh atmosphere in educational activities. This study aims to get an overview of the application of organic architecture to educational buildings. The method used is a descriptive qualitative analysis of educational buildings based on the concept of organic architecture

Keywords: Organic Architecture, Educational Building, Architectural Concept

\section{Pendahuluan}

Arsitektur organik merupakan konsep arsitektur yang dicetuskan oleh Frank Lloyd Wright, yang kemudian disebarkan ke Eropa oleh muridnya.Arsitektur organik seringkali disamakan dengan arsitektur Fungsionalism. Namun pada dasarnya masing-masing memiliki prinsip yang berbeda.Arsitektur organik sudah pasti bersifat fungsional tetapi arsitektur fungsionalisme belum tentu bersifat organik.Arsitektur organik lebih mengacu pada keselarasan dengan alam sekitarnya, dapat bertahan sepanjang waktu dengan bentuknya yang dinamis dan harmonis dengan alam, serta fungsional terhadap fungsi bangunannya. Cukup banyak para arsitek dunia yang menggunakan konsep arsitektur organik seperti Frank Lloyd Wright ini, diantaranya Antoni Gaudi, Rudolf Steiner, Bruce Goff, dan lain sebagainya dengan caranya masing-masing mengenai prinsip kehidupam alam.

Penggunaan konsep arsitektur organik yang terkenal dari Frank Lloyd Wright yaitu The Kaufman House yang berada di Pennsylvania atau sering disebut The Falling Water yang merupakan sebuah bangunan dengan fungsi hunian.Arsitek Frank Lloyd lebih sering menggunakan konsepnya ini pada bangunan tipe hunian.Tetapi, ada juga berbagai macam karya Frank Lloyd lainnya dengan tipe bangunan yang berbeda seperti bangunan komersial, religius, museum, pendidikan dan lain sebagainya.

Saat ini, tipe bangunan dengan penggunaan konsep arsitektur organik sudah banyak digunakan, salah satunya pada bangunan pendidikan. Fungsi bangunan pendidikan tidak lain merupakan sebuah fasilitas untuk memberikan pembelajaran, pengajaran, tukar menukar ilmu, memperdalam ilmu pengetahuan, dan sebagainya. Universitas sebagai bagian dari Pendidikan Tinggi, dihuni masyarakat dengan kebutuhan dan pemikiran yang lebih kompleks karena berada di jenjang yang paling tinggi.Oleh karena itu, masyarakat di Universitas membutuhkan fasilitas yang dapat menunjang kebutuhan dan pemikiran mereka dengan perasaan nyaman.

Masyarakat pengguna bangunan pendidikan akan merasa nyaman apabila bangunan dapat bersatu dengan lingkungan sekitarnya. Penerapan konsep arsitektur organik pada bangunan pendidikan dapat memperlihatkan bagaimana bangunan pendidikan menyelaraskan diri dengan alam tanpa merusak fungsi dari bangunan itu sendiri.Berdasarkan karya-karya dan sumber literatur yang terdahulu, peneliti dapat melakukan kajian konsep arsitekur organik ini yang diterapkan pada bangunan pendidikan.

\section{Kerangka Teoritis}

\section{Arsitektur Organik}

Organik berhubungan dengan kesatuan keterpaduan, yang berarti organik adalah bagian dari keseluruhan ataupun keseluruhan atas bagian (Widati, 2014). Kata organik dapat pula disebut sebagai suatu bahan atau benda yang merupakan bagian dari makhluk hidup. Namun dalam arsitektur, organik disebut sebagai kesatuan dan keseluruhan.

Dalam bukunya tentang Tokoh Arsitek Dunia, Dwijendra (2009) menceritakan bahwa arsitektur organik dicetuskan oleh Frank Lloyd Wright, namun kemudian konsepnya disebarkan ke eropa oleh muridnya yaitu Berlage dan J.J Oud. Pada saat usianya 9 tahun, Frank Lloyd tinggal dan bekerja di pertanian pamannya di dekat Spring Green. Di sinilah Frank memahami kesatuan antara manusia dan alam dalam pengaturan timbal balik dari suatu kelangsungan proses kehidupan, yang menjadi cikal bakal pemikirannya dalam arsitektur organik. 
Pemahaman arsitektur organik menurut Frank Lloyd Wright benar-benar mengutamakan segala aspek untuk mencapai keselarasan antara desain bangunan, manusia, dan lingkungannya.Karena tidak hanya dilihat dari satu sisi, melainkan dari berbagai sudut pandang hingga tercapainya keselarasan kehidupan.Menurut Rukayah (2003) arsitektur organik memperlihatkan shelter yang tidak hanyut sebagai kualitas ruang tetapi sebagai semangat dan faktor utama dalam konsep bangunan, manusia dan lingkungannya dalam suatu sosok yang nyata.Dalawir (2015) menyatakan bahwa arsitektur organik adalah filosofi arsitektur dimana tempat manusia berkegiatan selaras dengan alamnya.Desain dibuat harmonis dengan lokasi, lingkungan serta penataan bagian dalam bangunan.Bangunan disatukan dengan suatu komposisi yang saling berhubungan. berikut :

Karakteristik Arsitektur organik Frank Lloyd Wright menurut Rukayah (2003) adalah sebagai

1. Bentuk organik bukan diartikan sebagai bentuk imitasi dari alam akan tetapi sebuah pengertian dasar yang abstrak dari prinsip-prinsip alam.

2. Arsitektur organik adalah ekspresi kehidupan dari semangat hidup manusia.

3. Arsitektur organik adalah arsitektur kebebasan sebagai batas ideal dari demokrasi.

Konsep arsitektur organik yang dikemukakan oleh Frank Lloyd Wright seperti yang disampaikan oleh Nangoy (2016) adalah sebagai berikut :

1. Building as nature. Alam dijadikan sebagai gagasan atau ide dari bangunan arsitektur organik. Bentuk dan struktur mengacu pada sesuatu yang organis, sehingga desain tidak terbatas.

2. Continous present. Desain arsitektur organik harus dapat bertahan di sepanjang waktu. Desain harus mampu mengikuti perkembangan zaman. Meskipun demikian, unsur keaslian dan kenyamanan tetap diikutsertakan. Oleh karena itu, bangunan harus bisa mempertahankan dinamikanya dengan keadaan setempat.

3. Form Follows Flow. Alam dijadikan sebagai dasar penyesuaian desain. Oleh karena itu, aliran energi yang ada di alam sekitarnya harus dimasukkan ke dalam penyesuaian bentuk bangunan. Bentuk bangunan tidak boleh berlawanan dengan alam. Energi alam dapat berupa kekuatan dalam bumi, angina, panas, arus air, medan magner, dan lain sebagainya. Seluruhnya merupakan satu kesatuan yang tidak bisa dipisahkan.

4. Of the people. Perancangan bentuk dan struktur bangunan, didesain berdasarkan kebutuhan pemakai bangunan. Perancangan untuk kenyamanan pemakai bangunan juga sangat penting.

5. Of the hill. Bangunan organik jika menyatu dengan alam, akan terlihat tumbuh dan istimewa dari tapaknya. Bangunan tidak hanya diletakkan di atas tanah saja. Lokasi bukan menjadi penghalang bagi perancang untuk tetap mempertahankan keaslian alamnya. Solusi dapat dihasilkan dengan pemikiran yang luar biasa.

6. Of the materials. Material yang digunakan pada arsitektur organik selalu mendukung kualitas jiwa maupun karakter yang menjadi konsepnya. Tidak ada ketentuan penggunaan material secara terperinci. Namun dalam mendukung karakter bangunan, bisa saja menggunakan material yang tradisional, ekologi, maupun materi-materi baru lainnya.

7. Youthful and unexpected. Arsitektur organik punya karakternya sendiri. Terkadang desainnya terkesan menyimpang dari hal yang biasanya, bersifat menghasut bahkan anti dikuasai dengan bentuk lainnya. Bentuk arsitektur organik dapat terkesan muda dan unik.

8. Living music. Unsur musik modern dimuat dalam arsitektur organik. Terdapat kombinasi yang sesuai pada struktur dan proporsi bangunan yang tidak simetris. Arsitektur organik selalu berhubungan dengan masa depan dan bersifat modern.

\section{Bangunan Pendidikan Tinggi}

Menurut Broto (2011) disiplin pendidikan dan arsitektur jelas menyatakan bagaimana manusia telah berevolusi.dengan mempertimbangkan pengembangan salah satu bidang dapat 
merekonstruksi jalur panjang dan tidak teratur atau evolusi historis: dari kondisi sosial, agama atau ekonomi ke moral dan politik.Bangunan Pendikan adalah suatu bangunan yang di dalamnya memiliki fungsi dalam mewadahi seluruh kegiatan pembentukan, pengembangan, serta pembelajaran pribadi manusia. Bangunan pendidikan merupakan sarana yang ditujukan untuk mendukung seluruh proses pendidikan. Bangunan pendidikan yang baik dapat menciptakan manusia yang berkualitas baik pula.Menurut Badan Standar Nasional Pendidikan (2011) Pendidikan Tinggi sekurangkurangnya memiliki sarana dan prasarana yang dikelompokkan dalam sarana dan prasarana akademik yang terdiri atas sarana dan prasarana akademik umum dan akademik khusus, serta sarana dan prasarana non akademik yang terdiri dari sarana dan prasarana manajemen dan penunjang.

\section{Metode Penelitian}

Penelitian ini menggunakan metode penelitian deskriptif kualitatif. Metode penelitian deskriptif kualitatif ini merupakan metode penelitian dengan cara mengamati fakta-fakta maupun gambaran situasi yang ada yang kemudian dianalisis dengan mendeskripsikan serta mengidentifikasikan setiap aspek yang ada.Pendekatan penelitian yang digunakan pada penelitian ini yaitu pendekatan deduktif.Alat analisis yang digunakan adalah 8 (delapan) konsep Arsitektur Organik.Analisis yang dilakukan menggunakan dua tahap.Tahap pertama merumuskan konsep arsitektur organic menurut FL Wright.Tahap kedua mengidentifikasi dan mendeskripsikan konsep tersebut dengan melihat aplikasinya pada studi kasus.Hasil identifikasi dan deskripsi tersebut kemudian di analisis dan diinterpretasikan.



Gambar 1. Teknik Analisis Penelitian

Sumber: Pribadi, 2019

\section{Lokasi Penelitian}

Penelitian ini dilakukan dengan memilih 3 lokasi yakni 1) School of Art, Design and Media, NTU sebagai Kasus 1; 2) The Hive, NTU sebagai Kasus 2; 3) Perpustakaan Pusat, Universitas Indonesia sebagai Kasus 3.

\section{Hasil dan Pembahasan}

\section{Building As Nature}

Konsep building as nature merupakan konsep yang penerapannya akan membantu menjawab bentuk bangunan. Berdasarkan konsep building as nature ini, dapat dilihat penerapannya pada bentuk 
bangunan dan tata ruang luarnya. Pada bangunan School Of Art, Design And Media, bentuk bangunan yang terlihat yaitu membentuk dua lengkungan yang berada di dua sisi. Dengan atap yang menggunakan sistem roof garden, semakin membuat bangunan ini menyerupai alam sekitarnya yang berupa rerumputan.Pada sebelah bangunan School Of Art, Design And Media, terdapat tebing atau tanah miring yang berundak.Bentuk bangunan ini merespon tebing yang miring tersebut seperti yang terlihat pada Gambar berikut ini.

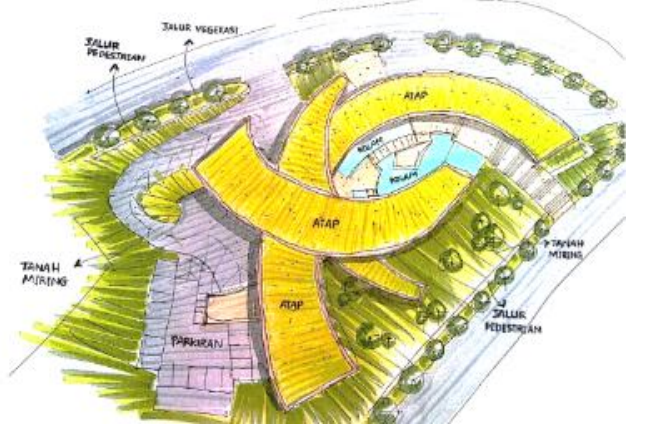

Gambar 2. School of Art, Design and Media

Sumber: Dokumen Pribadi, 2019

Konsep building as nature yang dimiliki bangunan School Of Art, Design And Media ini didasari pada bentuk bangunan yang mengikuti bentuk alamnya serta penataan vegetasi pada bangunan maupun pada tapak. Bentuk bangunan diadaptasi dari bentuk tanah yang berkontur.Penataan vegetasi bangunan disesuaikan dengan lingkungan alam yang ada.

Bentuk bangunan The Hive NTU ini terlihat seperti batang pohon dengan dedaunan yang tumbuh di sela-sela batang.Batang pohon dengan lengkungan-lengkugan yang semakin tinggi semakin besar.Warna bangunan ini yang cenderung memilih warna-warna alam yakni cokelat muda dan hijau pada vegetasinya, membuat bangunan ini sesuai dengan lingkungan alam yang ada.Bangunan lain yang ada di sekitarnya memiliki gaya arsitektur modern dengan penggunaan garis yang simetris secara dominan. Sedangkan bangunan The Hive NTU ini menggunakan bentuk bangunan yang lengkung yang merupakan bentuk organik.Bentuk bangunan disesuaikan dengan bentuk tapak yang tersedia, dengan memanfaatkan lahan yang minim dan membangunnya vertikal ke atas. Bangunan The Hive NTU tidak menggunakan bentuk yang sama dengan bangunan sekitarnya, namun masih terdapat usaha untuk menyesuaikan dengan lingkungannya. Hasil penyesuaian yang dilakukan yaitu dengan memberikan garis horizontal yang dominan pada seriap lengkungan yang ada untuk menyesuaikan dengan bangunan lama.Selain itu, penggunaan tanaman gantung serta beberapa tanaman lainnya yang terlihat di bangunan ini juga sebagai bentuk penyesuaian dengan lingkungan alami yang ada di sekitar bangunan.

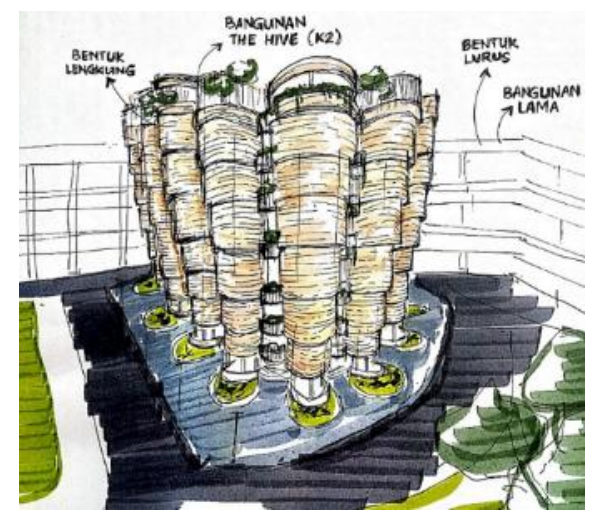

Gambar 3. The Hive, NTU 1

Sumber: Dokumen Pribadi, 2019 
Bentuk bangunan Perpustakaan Pusat UI tidak berbentuk lengkungan sepenuhnya, melainkan hanya pada bagian bawah atau bagian podium saja yang berbentuk melengkung, sedangkan bangunan di tengahnya berbentuk agak meruncing. Bentuk podium yang melengkung ini menyerupai bentuk bukit, sehingga terkesan merupakan bagian dari alam.Sedangkan, bentuk bangunan yang meruncing ini justru terlihat seperti tebing berbatu yang berada di tengah bukit.Berdasarkan bentuk bangunan yang dimiliki Perpustakaan Pusat UI ini, maka bangunan Perpustakaan Pusat UI memiliki penerapan konsep building as nature.Bentuk bangunannya menyerupai bentuk lingkungan alam. Penggunaan sistem green roof serta penataan ruang luar yang dimiliki bangunan ini semakin mendukung bangunan sehingga dapat menyesuaikan dengan lingkungan alamnya.

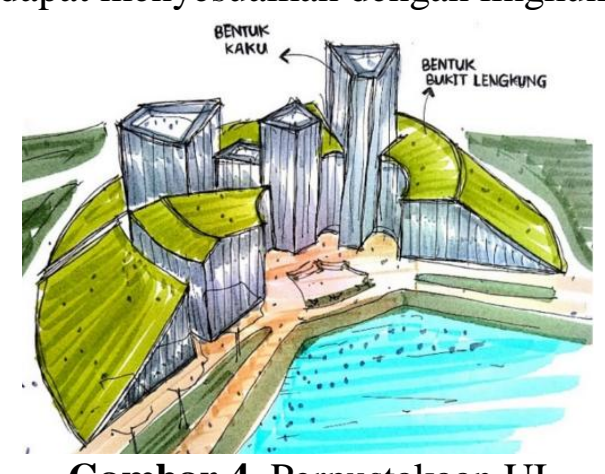

Gambar 4. Perpustakaan UI

Sumber: Dokumen Pribadi, 2019

\section{Continous Present}

Bangunan School Of Art, Design And Media mencoba memaksimalkan pencahayaan alami. Selubung bangunan yang transparan, mampu memasukkan cahaya matahari ke dalam bangunan secara maksimal.Selain itu, bentuk bangunannya yang dinamis berupa lengkungan, serta berbagai macam vegetasi yang ada juga membuat bangunan ini selaras dengan lingkungannya, seperti pada Gambar 5 dibawah ini.

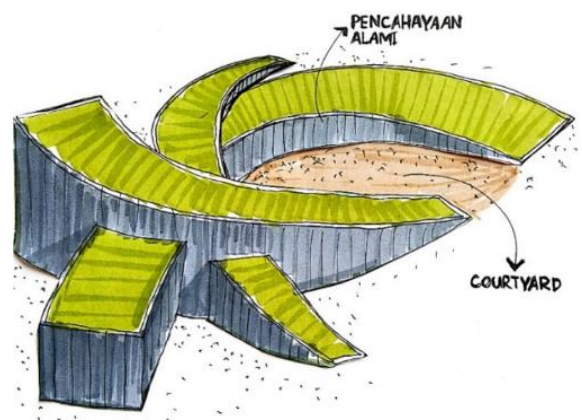

Gambar 5. Bentuk Massa Bangunan School Of Art, Design And Media Sumber: Dokumen Pribadi, 2019

Bangunan ini memiliki bentuk yang tidak biasa, yakni dengan menggunakan bentuk lengkung yang tidak simetris. Bentukan lengkungan ini tidak kaku dan selalu membawa unsur alami yang dimilikinya. Bangunan ini tampak segar dan asli sehingga dalam zaman apapun, bangunan ini akan mampu bertahan dengan segala perubahan pada lingkungan sekitarnya.

Bangunan The Hive NTU ini terdiri dari lengkungan yang cukup kompleks.Seluruh bagian bangunan ini terbuka sebagian, dan pada bagian atap menggunakan material transparan sehingga cahaya matahari dapat menerangi bagian dalam bangunan.Cahaya matahari yang masuk ke dalam bangunan cukup banyak tanpa terasa panas, karena bangunan juga dikelilingi celah-celah yang dapat 
dimasuki oleh udara alami, sehingga penghawaan alami dapat dimaksimalkan.Dapat dikatakan bahwa bangunan ini termasuk salah satu bangunan yang menggunakan konsep continuous present.Berdasarkan bentuk bangunannya yang disesuaikan dengan lingkungan alam, serta penggunaan beberapa prinsip yang mengutamakan kesegaran dan keaslian alam, bangunan The Hive NTU ini dapat terus bertahan dalam waktu apapun.Bentuknya memiliki bentuk yang tidak kaku dan dinamis dengan bentuk-bentuk organik.

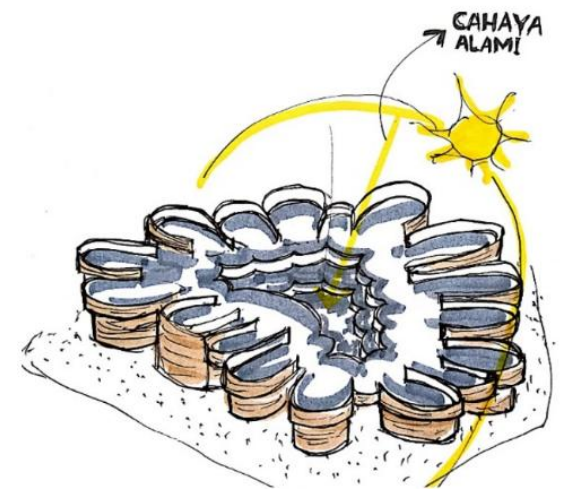

Gambar 6. Bentuk Massa Bangunan THE HIVE NTU

Sumber: Dokumen Pribadi, 2019

Bangunan Perpustakaan Pusat UI memiliki prinsip yang sama dengan bangunan School Of Art, Design And Media. Selubung bangunan ini menggunakan material yang transparan, sehingga cahaya matahari dapat secara maksimal masuk ke dalam bangunan, meskipun pada bagian dalam bangunan ini terdapat sekat-sekat lagi untuk memisahkan antar ruangnya.Bentuknya yang melengkung dan berpusat ke arah danau, menjadikan bangunan ini dinamis dengan lingkungannya. Vegetasi yang hadir di sekitar bangunan maupun pada bangunan, juga mampu membangun karakter yang sama dengan lingkungan sekitarnya. Desain bangunan Perpustakaan Pusat UI ini tidak akan ketinggalan zaman. Bangunan Perpustakaan Pusat UI ini dapat berkembang mengikuti zaman dengan desainnya yang menggunakan bentuk organik. Bentuk organik merupakan bentuk yang paling fleksibel dan alamiah, sehingga dimanapun bentuknya akan dapat diterima alam. Selain itu, bentuk bangunan yang mengutamakan kesegaran pada bagiannya, dapat mendukung bangunan Perpustakaan Pusat UI ini dapat terus diterima pada setiap zaman.

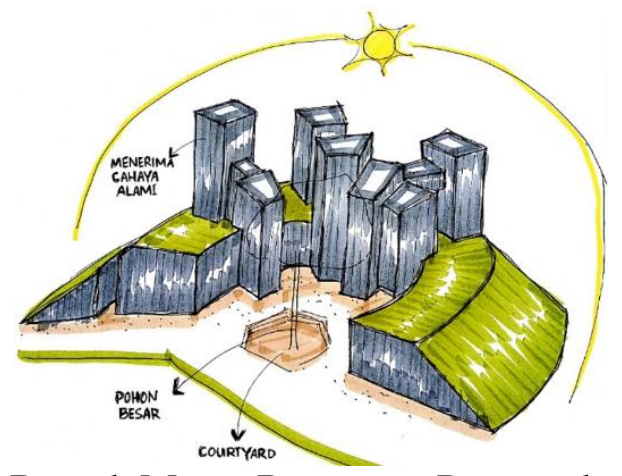

Gambar 7. Bentuk Massa Bangunan Perpustakaan Pusat UI

Sumber: Dokumen Pribadi, 2019

\section{Form Follows Flow}

Bentuk bangunan School Of Art, Design And Media mempertimbangkan energi internal maupun energi eksternal. Kebutuhan bangunan ini yang terdiri dari beberapa kegiatan, yakni berbagai macam program kelas yang tersedia turut membentuk bangunan dengan paduan massa yang terpusat. Selain itu, arah matahari dan arah angin pada site juga menjadi pertimbangan pembentukan 
massa bangunan, sehingga menghasilkan bentuk yang melengkung.Bentuk bangunan School Of Art, Design And Media menyesuaikan dengan aliran energi pada lingkungan yang ada. Bentuk bangunan disesuaikan dengan arah pergerakan matahari.Orientasi bangunan lebih condong ke arah selatan, dengan sisi bangunan yang panjang mengarah ke utara dan selatan.bentuk bangunan yang demikian dapat mengurangi panas radiasi matahari yang dipancarkan terhadap bangunan, sehingga pengguna di dalamnya bisa merasa kepanasan.

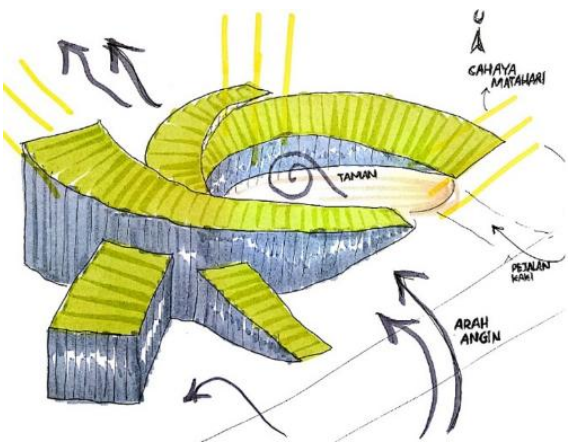

Gambar 8. Aliran Energi Bangunan School Of Art, Design And Media Sumber: Dokumen Pribadi, 2019

Bentuk bangunan The Hive NTU ini memiliki detail yang banyak. Seluruh sisi bangunannya berupa kumpulan lengkungan pada tapak yang datar.Bentuk bangunan ini mengikuti bentuk tapak yang juga tidak beraturan.Bukaan-bukaan pada bangunan ini dibuat diseluruh sisi bangunan untuk membiarkan angin masuk ke dalam bangunan.Arah matahari juga sebagai acuan dalam desain bentuk bangunan The Hive NTU ini, yakni dengan proporsi bangunan yang memanjang ke arah Barat-Timur. Tatanan massa bangunan The Hive NTU dapat dilihat pada Gambar 9 dibawah ini.

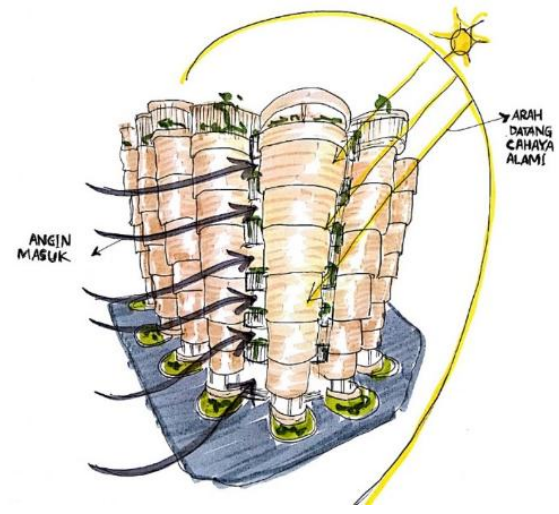

Gambar 9. Aliran Energi Bangunan THE HIVE NTU

Sumber: Dokumen Pribadi, 2019

Berdasarkan bentuk bangunan yang ada di tapak, bangunan The Hive NTU ini meletakkan sisi bangunan yang panjang menghadap ke arah utara dan selatan.Sehingga bangunan ini dapat mengikuti aliran energi yang dipengaruhi oleh luar tapak.Selain itu, adanya bukaan pada setiap sudut bangunan semakin membuat bangunan ini dapat dialiri oleh energi angin dari luar bangunan.

Bangunan Perpustakaan Pusat UI ini membentuk pusat pada bagian tengahnya.Namun pusat yang berada di tengah ini juga berpusat pada keadaan lingkungan yang ada di depannya, yaitu keberadaan danau.Sehingga pada bagian yang berada di dekat danau, bentuk massanya terpotong sehingga terbuka ke arah danau.Bangunan Perpustakaan Pusat UI ini mengikuti aliran energi dari danau yang ada di sekitarnya. Hal ini menyebabkan arah orientasi bangunan menuju ke arah danau.Danau berada di arah selatan bangunan. Angin dari arah danau dapat berhembus secara kencang dan menabrak massa bangunan Perpustakaan Pusat UI. Pohon besar diletakkan di sekitar bangunan untuk mengurangi kecepatan angin yang menghembus.Selain untuk meminimalisir 
hembusan angina kencang, pohon besar yang diletakkan di bagian plaza maupun sekitar bangunan Perpustakaan Pusat UI juga dapat mengurangi panas yang di pancarkan dari arah tersebut.

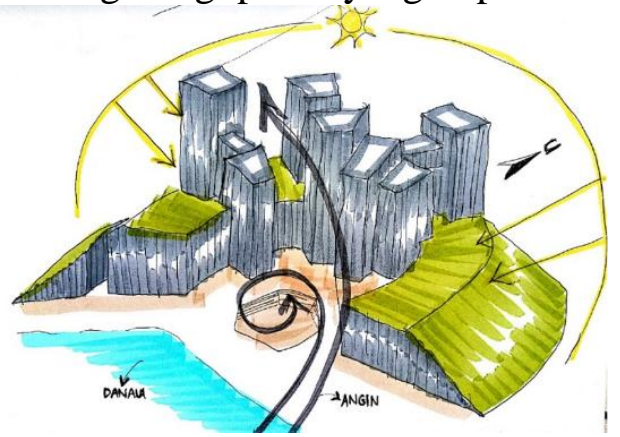

Gambar 10. Aliran Energi Bangunan Perpustakaan Pusat UI Sumber: Dokumen Pribadi, 2019

\section{Of The People}

Bangunan School Of Art, Design And Media ini mewadahi aktivitas manusia yang ada di dalamnya berdasarkan peruntukan fungsi bangunannya. Bangunan ini merupakan Sekolah Seni, Desain dan Media yang berada di lingkungan Nanyang Technological University. Bagian dalam bangunan ini terdiri dari beberapa fasilitas yang mendukung seperti panggung, laboratorium, toko, kantor, ruang media, studio, gallery, dan sebagainya yang mendukung kegiatan tersebut. Ruangruang ini terhubung satu sama lain berdasarkan kelompoknya. Berdasarkan bentuk ruang yang tersedia di dalam bangunan School Of Art, Design And Media, bentuk dan ukuran ruang dapat memberikan kenyamaan yang cukup untuk pengguna yang ada di dalamnya.Bentuk ruang yang relatif besar dan luas, serta efektif dalam pembagian ruangnya dapat membuat orang yang beraktivitas di dalamnya merasa nyaman. Pembagian ruang tersebut didasarkan pada grid radial sehingga berpusat pada satu titik yang sama pada setiap lengkungan.

Bangunan Perpustakaan Pusat UI ini merupakan fasilitas tempat belajar atau Learning Center yang juga berada di lingkungan Nanyang Technological University. Di dalamnya terdapat ruang belajar terbuka maupun tertutup.Ruang belajar terbuka ini tidak dibatasi oleh dinding, dan berbaur antara satu meja dengan meja lainnya yang diletakkan pada jarak yang terukur. Sedangkan ruang belajar yang tertutup ini dibatasi oleh dinding, baik transparan maupun massif.Selain itu, dilengkapi fasilitas yang menyediakan makanan, serta beberapa fasilitas servis lainnya yang mendukung aktivitas di dalam bangunan ini. Berdasarkan bentuk ruang yang ada pada bangunan The Hive NTU, bentuk tersebut dapat menciptakan suasana yang kreatif bagi pengguna bangunan. Ruang sirkulasi yang dibuat dengan lebar yang hampir sama dengan lebar setiap ruangnya dapat menunjang kenyamanan pengguna dalam mengakses setiap ruangnya. Void atau bukaan yang ada, didesain agar dapat menunjang kenyamanan pengguna bangunan.

Bangunan Perpustakaan Pusat UI ini merupakan bangunan Perpustakaan Pusat yang berada di area Universitas Indonesia. Di dalamnya terdapat berbagai fasilitas untuk membaca referensi, baik itu referensi fisik maupun referensi digital.Ruang baca yang tersedia berada di dalam area penyimpanan buku. Selain itu, ada berbagai fasilitas lainnya yang mendukung aktivitas di dalamnya seperti, retail, kantor administrasi, dan lain sebagainya yang saling berhubungan sesuai dengan kelompoknya. Berdasarkan bentuk ruang bangunan Perpustakaan Pusat UI yang ada pada denah, bentukan ruang di desain dengan berpusat pada satu titik.Pusat titik yang menjadi acuan dalam pembagian bentuk ruang dapat memberikan kenyamanan yang cukup bagi pengguna bangunan.Meskipun bentuk ruangan melengkung, namun sudut yang terbentuk untuk membagi ruang serupa dengan sudut siku-siku yang ideal bagi ruang dengan bentuk radial. 


\section{Of The Hill}

Bangunan School Of Art, Design And Media berada di kawasan NTU yang memang berada di kawasan bangunan pendidikan. Oleh karena itu, setiap bagian bangunannya telah memiliki lahan sendiri untuk dibangun sesuai bidang dan peruntukannya.Lahan yang dimilik bangunan School Of Art, Design And Media ini cukup luas, sehingga ada banyak ruang hijau yang tersisa. Bangunan School Of Art, Design And Media ini seolah tumbuh dan menjadi bagian dari lingkungan alam yang ada di sekitarnya. Hal ini dikarenakan bentuk bangunan yang menyerupai bentuk bukit dengan landaian pada setiap salah satu sisinya. Selain itu bentuk kreatif muncul dengan adanya permainan bentuk lengkungan-lengkungan yang saling bertemu.

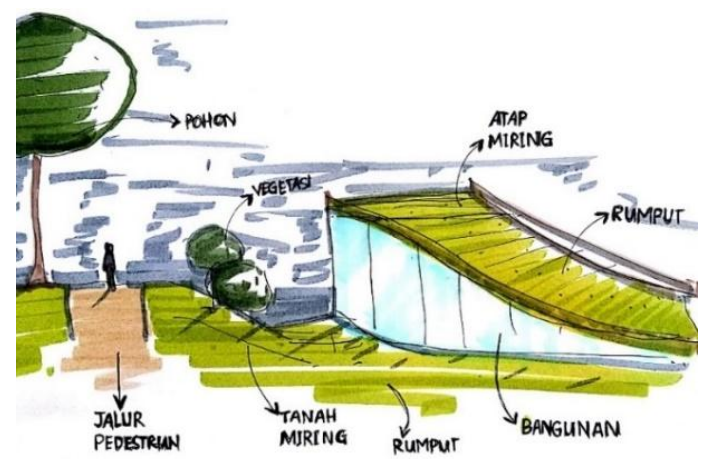

Gambar 11. Bangunan School Of Art, Design And Media dan lingkungannya Sumber: Dokumen Pribadi, 2019

Berdasarkan bentuk bangunan yang terbentuk di sebuah lahannya, bangunan School Of Art, Design And Media ini cukup unik dalam menyesuaikan diri dengan tapaknya. Bentuk bangunan dibuat melengkung sesuai dengan salah satu sisi tapak, dan sisi tapak lainnya yang berbentuk lurus juga dibentuk bangunan yang melengkung.Selain itu, bangunan yang didesain juga disesuaikan dengan arah terbit dan terbenam matahari, arah sirkulasi di luar tapak, serta arah angin.

Bangunan The Hive NTU ini berada di sebuah tapak dengan bangunan sekitar yang sebelumnya sudah berdiri sebelum bangunan The Hive NTU dibangun.Tapak bangunan The Hive NTU ini memiliki bentuk yang tidak beraturan, sehingga menjadi tantangan tersendiri untuk mendesain bangunan The Hive NTU. Bentuk bangunan tidak dibetuk linear sejajar dengan bentuk tapak, melainkan membentuk bentuk yang baru dari tapak tersebut.Bentuk lengkungan yang dipilih pada bangunan The Hive NTU ini disesuaikan dengan analisa iklim dan lingkungan yang ada di daerah tersebut.Berdasarkan bentuk bangunan pada bangunan The Hive NTU, maka bentuk bangunan ini dapat dikatakan bentuk yang tumbuh dari tapak. Bentuknya yang unik dan tidak biasa, merupakan hasil proses analisa dari lingkungan sekitar. Kondisi lingkungan yang ada di sekitarnya seperti sirkulasi, serta pergerakan lalu lintas juga menjadi salah satu penentu desain bangunan The Hive NTU.

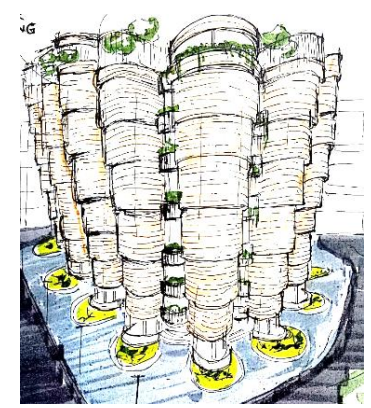

Gambar 12. Tapak Bangunan THE HIVE NTU

Sumber: Dokumen Pribadi, 2019 
Bangunan Perpustakaan Pusat UI ini juga merupakan bangunan pendidikan yang tapaknya sudah disediakan berdasarkan peruntukanya.Bangunan Perpustakaan Pusat UI ini juga berada di lingkungan pendidikan yang juga berperan sebagai pembentuk desain Bangunan Perpustakaan Pusat UI. Berdasarkan lokasi dan sirkulasi yang ada, bentuk bangunan disesuaikan dengan eksisting yang telah ada.Sirkulasi dan pencapaian menuju tapak dianalisa sehingga mempengaruhi desain bangunan Perpustakaan Pusat UI. Hal yang dipengaruhi yakni peletakan Main Entrance yang berada di dua sisi bangunan.Peletakan jalur service yang juga disesuaikan dengan sirkulasi yang ada.Berdasarkan sirkulasi dan pencapaian yang ada terhadap tapak bangunan Perpustakaan Pusat UI, maka bangunan tersebut merupakan bagian dari site.Sehingga segala aspek yang ada di dalam tapak mempengaruhi desain bangunan Perpustakaan Pusat UI ini. Selain itu, aspek-aspek lingkungan yang lain seperti arah terbit dan terbenam matahari juga sebagai salah satu faktor desain yang dibuat.

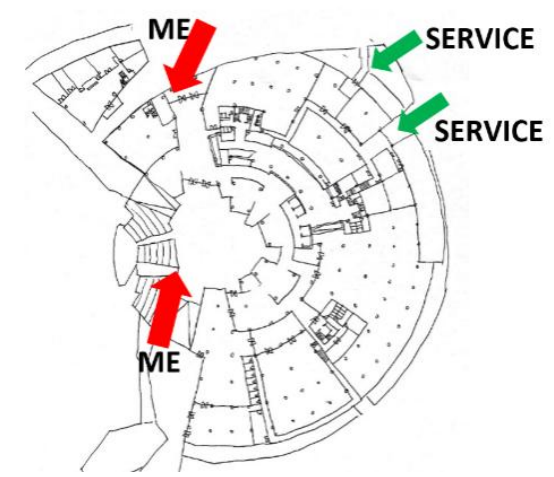

Gambar 13. Kondisi Tapak Bangunan Perpustakaan Pusat UI

Sumber: Dokumen Pribadi, 2019

\section{Of The Material}

Material utama yang membentuk bangunan School Of Art, Design And Media ini adalah beton. Beton adalah campuran antara semen Portland atau semen hidraulik, agregat halus, agregat kasar, dan air dengan atau tanpa bahan tambahan yang membentuk massa padat (Kandi et al., 2012). Beton bertulang digunakan untuk membentuk struktur utama bangunan yakni dari bagian pondasi hingga atap bangunan.Material lain yang digunakan sebagai selubung bangunan School Of Art, Design And Media ini adalah kaca.Kaca yang digunakan ini dapat menghadirkan cahaya matahari langsung maupun pantulan yang dapat masuk ke dalam bangunan, sehingga dapat meminimalisir penggunaan cahaya buatan di dalam bangunan.

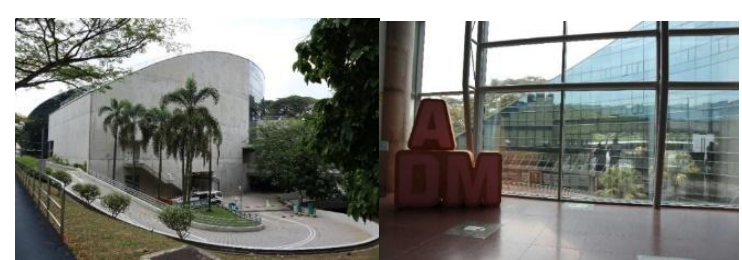

Gambar 14. Material Beton dan Kaca School Of Art, Design And Media Sumber : Dokumen Pribadi, 2018

Bangunan The Hive NTU menggunakan material utama beton.Beton dalam bangunan ini sangat di ekspose sehingga dapat dengan jelas terlihat. Beton digunakan sebagai struktur utama bangunan tanpa menggunakan bahan pelapis lain kecuali pada bagian selubung bangunan. 


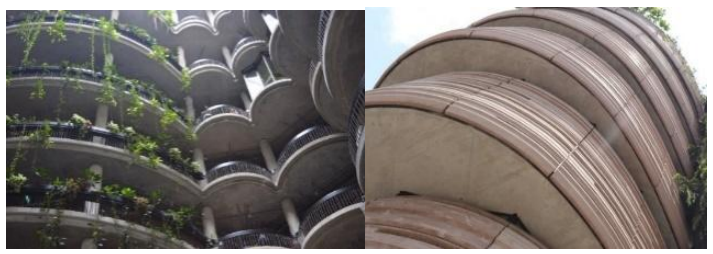

Gambar 15. Material Beton School Of Art, Design And Media

Sumber: Dokumen Pribadi, 2018

Selubung bangunan The Hive NTU menggunakan beton yang dicetak dengan bentuk tertentu.Bentuk dari cetakan ini membentuk garis linear horizontal dengan lengkungan pada setiap garisnya. Cetakan beton untuk selubung bangunan ini berbentuk lengkungan untuk menyesuaikan dengan bentuk plat lantai yang telah dibangun.

Bangunan Perpustakaan PusAT UI ini sama seperti bangunan School Of Art, Design And Media dan The Hive NTU. Material pembentuk bangunan yang utama yakni beton. Beton digunakan sebagai struktur utama pembentuk pondasi, lantai kolom, balok, atap, dan bagian lainnya. Penggunaan material beton ini tidak terlihat karena dilapisi lagi dengan material lainnya.Pada bagian selubung bangunan, menggunakan material keramik dengan tekstur kasar dan berwarna gelap. Selain itu terdapat beberapa bagian dengan material yang sama namun dengan warna yang lebih terang diselingi dengan warna yang gelap.Selain penggunaan material keramik, terdapat penggunaan material lain berupa kaca.Penggunaan material kaca ini juga berwarna abu-abu tua dan warna abuabu agak terang. Perbedaan warna ini membuat gradasi fasad sehingga menampilkan kesan tertentu.

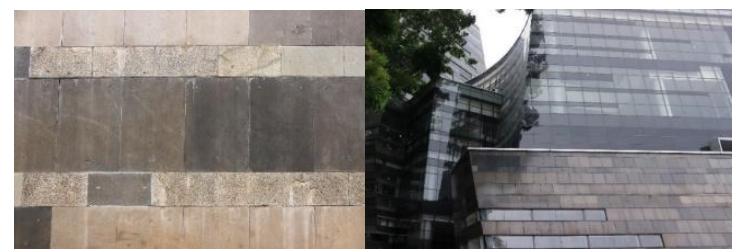

Gambar 16. Material Selubung Perpustakaan Pusat UI Sumber: Dokumen Pribadi, 2018

\section{Youthful and Unexpected}

Bentuk bangunan School Of Art, Design And Media memiliki keunikan tersendiri. Bentuk lahan yang dimiliki bangunan School Of Art, Design And Media ini tidak beraturan namun memiliki bagian yang melengkung.Desain bangunan ini dibuat melengkung dengan lengkungan yang menghadap ke berbagai arah namun tetap berorientasi pada satu tiitk pusat, yakni bagian tengah. Bentuk bangunan School Of Art, Design And Media cukup bisa ditebak dengan adanya lengkungan pada salah satu bagian tapak. Namun bentuk bangunan yang terdiri dari beberapa lengkungan yang berpusat tersebut merupakan ide yang unik dan tidak terduga.

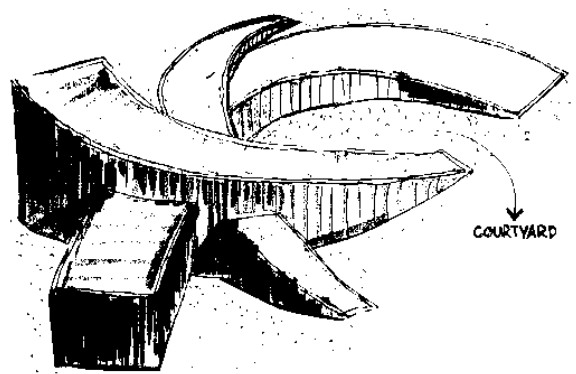

Gambar 17. Bentuk Bangunan School Of Art, Design And Media Sumber: Dokumen Pribadi, 2019 
Bentuk bangunan The Hive NTU dapat dikatakan sangat unik.Bentuk tapak yang ada pada bangunan ini merupakan benuk yang tidak beraturan.Sehingga desain bangunan The Hive NTU tidak dapat diperkirakan. Selain itu keadaan bangunan sekitar yang telah berdiri sebelumnya serta keadaan tapak yang terbatas juga membuat desain pada bangunan The Hive NTU ini sulit untuk diduga. Bentuk bangunan justru terdiri dari lengkungan-lengkungan menyerupai balon lonjong yang saling bertemu dan menempel.

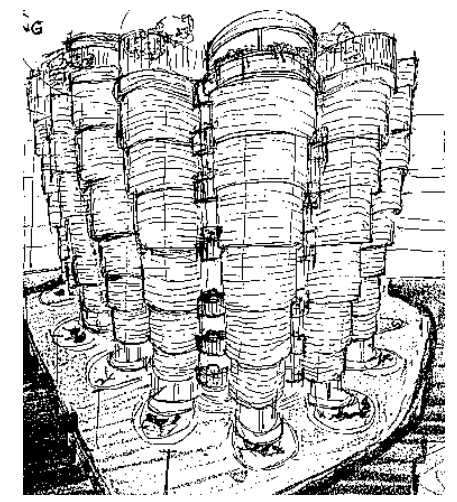

Gambar 18. Bentuk Bangunan THE HIVE NTU

Sumber: Dokumen Pribadi, 2019

Berdasarkan bentuk bangunan The Hive NTU, maka bangunan The Hive NTU ini memiliki bentuk yang sangat unik dan tidak dapat diduga karena lengkungannya yang bersifat acak.Selain itu bangunan The Hive NTU ini terlihat seperti bangunan individual yang membentuk dirinya sendiri, karena bentuknya yang berbeda dengan bangunan yang ada di sekitarnya.Aksen yang dimiliki bangunan The Hive NTU ini cukup berbeda dengan bangunan lainnya. Hal ini dikarenakan pada bagian dinding bangunan ini digunakan selubung yang membentuk garis-garis horizontal yang berurutan dari bagian atas bangunan hingga ke bawah.

Pada bangunan Perpustakaan Pusat UI, desain bangunan ini juga memiliki keunikan tersendiri. Terletak di pinggir danau dan dikelilingi dengan bangunan-bangunan arsitektur bergaya arsitektur tradisional Indonesia.Bangunan Perpustakaan Pusat UI ini membentuk bangunannya dengan sebuah lengkungan yang mengelilingi sebuah batangan-batangan yang ada di tengahnya. Desain yang tidak biasa, dan sangat menarik perhatian bagi orang yang melihatnya.Bentuk-bentuk batangan yang tidak beraturan dengan ketinggian yang berbeda juga menambah aksen yang sangat tidak terduga.Berdasarkan bentuk bangunan pada Perpustakaan Pusat UI, maka bangunan ini memiliki bentuk yang sangat unik dan tidak biasa.Bangunan ini memiliki karakter yang cukup kuat sehingga dapat berdiri sendiri dan mempertahankan karakternya.Oleh karena ini, bangunan ini dapat memberikan kesan tersendiri berdasarkan bentuk bangunannya.

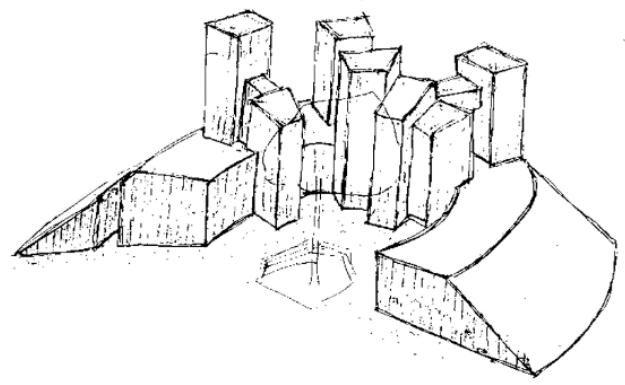

Gambar 19. Bentuk Bangunan PERPUSTAKAAN PUSAT UI Sumber: Dokumen Pribadi, 2019 


\section{Living Music}

Bangunan School Of Art, Design And Media ini memiliki bentuk bangunan yang melengkung. Lengkungan-lengkungan yang menjadi bentuk dasar bangunan School Of Art, Design And Media ini memiliki ketinggian dan besaran luas massa yang berbeda. Setiap massa yang membentuk lengkungan ini memiliki porsi masing-masing dalam membentuk satu kesatuan bangunan School Of Art, Design And Media. Lengkungan yang dimiliki bangunan School Of Art, Design And Media tidak simetris, sehingga tidak dapat disamakan antara satu lengkungan dengan lengkungan lainnya. Penggunaan fasad yang bermaterial kaca, menunjukkan kesan bangunan yang lebih futuristik dan modern.

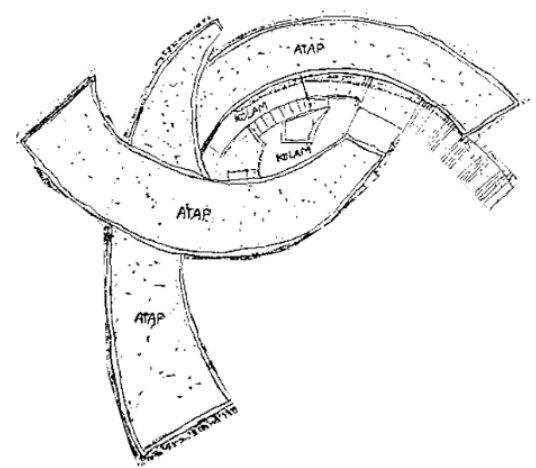

Gambar 20. Irama Bentuk Bangunan SCHOOL OF ART, DESIGN AND MEDIA

Sumber: Dokumen Pribadi, 2019

Berdasarkan bentuk bangunan School Of Art, Design And Media, maka dapat disimpulkan bahwa bangunan School Of Art, Design And Media ini memiliki keselarasan irama dengan bentuk yang tidak simetris. Selain itu proporsi setiap massa yang mengisi bangunan School Of Art, Design And Media ini terasa pas dan seimbang. Selain itu, meskipun arsitektur organik merupakan arsitektur yang menyesuaikan dengan lingkungannya, namun kesan futuristik dan modern dapat diperoleh pada bangunan ini.

Bangunan The Hive NTU memiliki bentuk bangunan yang melengkung. Lengkunganlengkungan yang dimiliki bangunan The Hive NTU ini merupakan satu massa bangunan. Satu massa bangunan tersebut membentuk bagian luar bangunan yang menonjol di setiap sisinya. Setiap tonjolan yang dihasilakan pada bangunan ini tidak selalu sama, hanya memiliki irama yang selaras. Selain itu pada setiap lantai bangunan ini, memiliki ukuran yang berbeda, cenderung semakin besar semakin tinggi lantainya. Namun berbeda dengan Bangunan School Of Art, Design And Media, bangunan The Hive NTU ini tidak menggunakan material kaca pada bagian selubung bangunannya, sehingga kesan futuristik tidak didapatkan pada bangunan The Hive NTU.

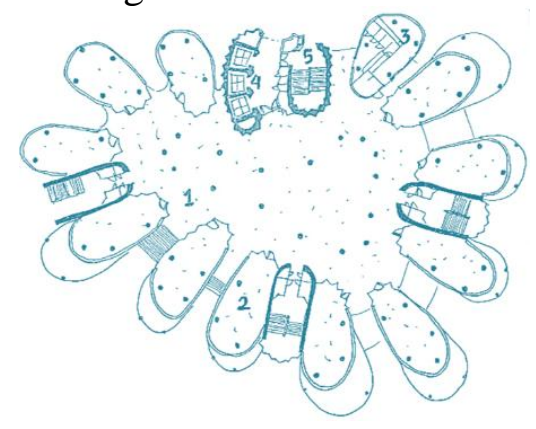

Gambar 21. Irama Bentuk Bangunan The Hive NTU

Sumber: Dokumen Pribadi, 2019

Berdasarkan bentuk bangunan The HivE NTU, maka dapat disimpulkan bahwa bentuk bangunannya memiliki keselarasan irama. Dengan adanya perbedaan besaran ruang pada setiap 
lantainya, membuat bangunan The Hive NTU ini memiliki proporsi bangunan yang tidak simetris.Selain itu, bangunan The Hive NTU ini tidak memberikan kesan futuristik seperti pada bangunan School Of Art, Design And Media.

Bangunan Perpustakaan Pusat UI ini memiliki bagian bangunan yang seirama pada bagian podium.Bagian podium ini merupakan bagian bangunan yang berbentuk melengkung di bagian bawah bangunan. Seluruh bagiannya sama besar dan sama tinggi. Namun pada bagian tengah bangunan ini, terdapat massa bangunan yang berbentuk batangan dengan pola yang hampir serupa pada setiap bangunannya. Massa bangunan Perpustakaan Pusat UI yang membentuk batangan ini memiliki ketinggian yang berbeda-beda pada setiap bagiannya.Meskipun demikian, bentuk bangunan Perpustakaan Pusat UI ini tampak seirama dan memiliki proporsi yang seimbang.

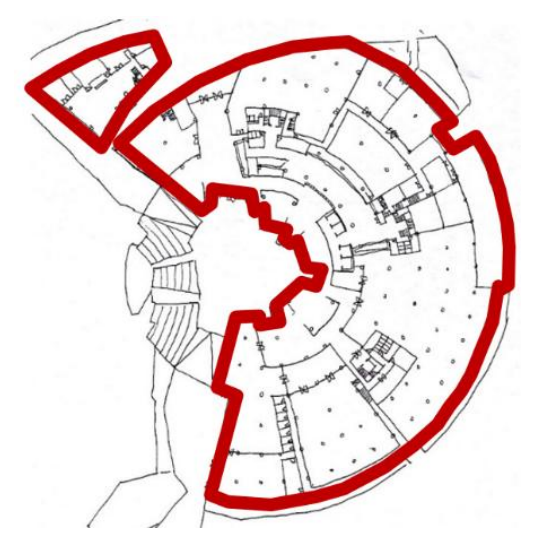

Gambar 22. Irama Bentuk Bangunan Perpustakaan Pusat UI Sumber: Dokumen Pribadi, 2019

Berdasarkan bentuk bangunan Perpustakaan Pusat UI, maka dapat disimpulkan bahwa bentuk bangunan Perpustakaan Pusat UI ini memiliki keselarasan irama pada bentuk bangunannya. Selain itu bentuk bangunan yang tidak simetris dapat menghidupkan bangunan. Penggunaan material kaca pada bagian selubungnya memberikan kesan futuristik dan modern pada bangunan Perpustakaan Pusat UI.

\section{Kesimpulan}

Berdasarkan kajian yang telah dilakukan, maka dapat diperoleh kesimpulan bahwa arsitektur organik adalah konsep arsitektur yang menjadikan alam sebagai acuan berpikir dalam suatu gagasan atau desain. Tidak hanya didasarkan pada satu aspek, tetapi mengutamakan segala aspek agar tercipta desain ataupun gagasan yang dapat menyelaraskan antara manusia, ruang, dan lingkungannya. Karakteristik arsitektur organik didasarkan pada bentuk yang diartikan dari prinsip alam, terdapat makna kehidupan manusia di dalamnya, serta unsur kebebasan digunakan sebagai batasan yang sesuai dari persamaan pandangan hidup. Konsep arsitektur organik meliputi beberapa hal seperti building as nature, continuous present, form follows flow, of the people, of the hill, of the materials, youthful and unexpected, dan living music.

Bangunan pendidikan merupakan bangunan yang difungsikan untuk kegiatan pembentukan, pengembangan, serta pembelajaran pribadi manusia. Bentuk-bentuk pendidikan diantaranya adalah pendidikan anak usia dini, pendidikan dasar, pendidikan menengah, pendidikan tinggi, pendidikan non-formal, pendidikan keagamaan, serta pendidikan khusus. Berdasarkan hasil penelitian ada beberapa konsep arsitektur organik yang diterapkan pada bangunan pendidikan.

Penerapan konsep arsitektur organik pada bangunan pendidikan yang telah diteliti diketahui bahwa bangunan cenderung berbentuk menyesuaikan dengan alam disekitarnya. Rata-rata bangunan menggunakan bentuk-bentuk organik yakni berbentuk lengkungan yang tampak hidup. Bentuk 
bangunan dibuat tidak kaku sehingga terkesan fleksibel dengan keadaan alamnya. Pembawaan unsur alam ke dalam desain bangunan, memungkinkan bangunan akan bertahan sepanjang waktu dengan segala perubahan lingkungan yang ada. Bentuk bangunan mempertimbangkan energi-energi yang ada di tapak, baik itu energi eksternal maupun internal. Bentuk bangunan disesuaikan dengan aliran kebutuhan penggunanya.Bangunan didesain agar tampak tumbuh dari tapak yang ada, bukan merupakan bagian yang terpisah. Bangunan menggunakan material yang memenuhi syarat dalam membangun karakter dari bangunannya sendiri.Rata-rata material yang digunakan yakni berupa beton, kaca, serta batu alam.Setiap desain bangunan memiliki keunikan dan karakter sendiri. Ratarata bangunan menggunakan bentuk yang unik dan berkarakter kuat.Irama dari bentuk bangunan terbentuk mengikuti alirannya, disesuaikan dengan keadaan tapak dan lingkungannya.

\section{Daftar Pustaka}

Badan Standar Nasional Pendidikan (2011).Rancangan Standar Sarana dan Prasarana Pendidikan Tinggi Program Pascasarjana dan Profesi.

Broto, C (2011). Educational Facilities. Barcelona: Links.

Dalawir, A. M. P., Sony T., Hanny P (2017). Sentra Industri Kain Koffo Di Manganitu (Arsitektur Organik). Manado: Universitas Sam Ratulangi.

Dwijendra, N. K. A (2009).Tokoh Arsitek Dunia dan Karyanya. Bali: Udayana University Press.

Nangoy, W. M., Rieneke L. E. S (2016). Optimalisasi Konsep Building As Nature Dari Pendekatan Arsitektur Organik Pada Kawasan Industri Peternakan Berkonsep Agrowisata. Jurnal Media
Matrasain 13(1). Manado: Universitas Sam Ratulangi.

Republik Indonesia. Undang - Undang No. 20 Tahun 2003 tentang Sistem Pendidikan Nasional.

Rukayah, S (2003). Penekanan Desain Arsitektur Organik dan Green Architecture Pada Perancangan Pusat Rekreasi dan Klub Pemancingan Di Rawapening, Kabupaten Semarang. Semarang: Universitas Diponegoro.

Widati, T (2014). Rumah Usonian Sebagai Penerapan Arsitektur Organik Frank Lloyd Wright. Jurnal Perspektif Arsitektur 9(2). Kalimatan Tengah: Universitas Palangka Raya. 